\title{
Die Rechtsuerbältmisse
}

der

\section{geschlossenen Gesellschaften \\ und Jereine}

nach preussischem Recht

unter besonderer Berücksichtigung der Béfugnisse der Polizeibehörden.

Uon Dr. jur. 5. Delius

Candgerichtsrath.

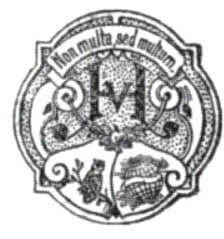

Berlin 1902.

J. J. Feines Uerlag. 
